\title{
IMPLEMENTATION OF VILLAGE BUSINESS MANAGEMENT BOARD (BUMDes) VILLAGE OF CIBALANARIK, TANJUNGJAYA DISTRICT TASIKMALAYA REGION
}

\author{
Deni Sudrajat $^{1}$, Tine Badriatin ${ }^{2}$ \\ ${ }^{1}$ STIA YPPT Priatim, Tasikmalaya, Indonesia, \\ ${ }^{2}$ Universitas Siliwangi, Tasikmalaya, Indonesia \\ ${ }^{1}$ sudrajatdeni74@yahoo.co.id, ${ }^{2}$ tinebadriatin@gmail.com
}

\begin{abstract}
This study aims to determine and analyze the implementation of the management of the Cibalanarik Village-Owned Enterprises of Tanjungjaya District, Tasikmalaya Regency. The implementation can be seen from the factors of policy size and objectives, resources, characteristics of implementing agents, disposition of implementers, communication between organizations and implementing activities. The research method used is qualitative methods through observation and in-depth interviews with people who have information related to the management of the Cibalanarik Village-Owned Enterprises in the Tanjungjaya District of Tasikmalaya Regency. Data analysis technique is done through data reduction, data display up to the conclusion. Based on the results of the study showed that the implementation of the management of the Entrepreneurship of the Village of Cibalanarik, Tanjungjaya District, Tasikmalaya Regency. Implementation can be effective by fulfilling aspects of achieving policy objectives, availability of resources, the ability of the implementers / managers of Village-Owned Enterprises, the spirit required to build and develop Village-Owned Enterprises, and the ability to communicate with various parties.
\end{abstract}

Keywords: Implementation of Policies, Village-Owned Enterprises

\section{A. Introduction}

Village-owned enterprises (BUMDes) are village businesses managed by the Village Government, and are incorporated. The village government can establish a villageowned enterprise in accordance with the needs and potential of the village. Establishment of Village-Owned Enterprises is stipulated by Village Regulation. Management of Village Owned Enterprises consists of the
Village Government and the local village community

Village Owned Capital may come from the Village Government, community savings, Government assistance, Provincial Governments and Regency / City Governments, loans, or other parties' equity participation or profit-sharing cooperation on the basis of mutual benefit. Village-Owned Enterprises 
can make loans, which can be done after obtaining BPD approval.

Village Fund Allocation is a fund allocated by the Regency / City Government for the village, which is sourced from the central and regional financial balance funds received by the Regency / City. The Village Income and Expenditure Budget, hereinafter abbreviated as APB Desa is the annual village government financial plan discussed and jointly agreed by the Village Government and BPD, which are stipulated by the Village Regulation.

One of the hopes of establishing a Village-Owned Enterprise (BUMDesa) is to create a prosperity leap for villages in Indonesia that is not really an empty hope. BUMDesa has all the power to get there starting from state support in the form of Law Number: 6 of 2014 on Villages to the funds disbursed directly by the government to the villages to achieve this goal.

Management of Village Owned Enterprises (BUMDes), currently still experiencing various obstacles and challenges faced by villages in various corners of Indonesia, so that until now the management of BUMDes is still largely not optimal. The Ministry of Villages for Disadvantaged Regions and Transmig-ration noted that until 2017, only 4,000 BUMDes have managed to get profits as a business entity.

Management of Village Owned Enterprises (BUMDes) which are still not optimal in carrying out their business activities, one of them is Cibalanarik Village, Tanjungjaya District, Tasikmalaya Regency, where from the existing phenomena, its management still experiences various obstacles and challenges so that the business program that is run is not in accordance with the plan and programs created before. Various attempts have been made but still experience various losses, it is allegedly still weak supervision in its management.

Therefore the purpose of community service in Cibalanarik Village is to provide assistance in the form of BUMDes management discussion so that the implementation 
of perda no. 6 of 2016 can be effective by fulfilling aspects of achieving policy objectives, availability of resources, the ability of BumDes implementers / managers, the spirit of building and developing BumDes is needed, and the ability to communicate with various parties.

Implementation is very important to be carried out on the existence of a policy that has been formulated, because without the implementation of a policy only records that do not have the meaning and benefits as the purpose of making a policy. According to Grindle (1980: 7) states that implementation is a general process of administrative action that can be examined at a particular program level. Meanwhile, according to Van Meter and Horn in Wibawa, et al., (1994: 15) states that the implementation of policy is an action taken by the government and the private sector both individually and in groups intended to achieve goals.

So this BUMDes can developing and becoming a competitive village economic institution, then it is necessary to categorize the level of development of BUMDes based on its development status, where this categorization can help the government in decision making (Harmiati, Abdul Aziz Zulhakim : 2017)

\section{B. Method of Implementation}

The research method used is a qualitative method through observation and in-depth interviews with people who have information related to the management of the Cibalanarik Village-Owned Enterprises (BumDes) of Tanjungjaya District, Tasikmalaya Regency. Data analysis technique is done through data reduction, data display up to the conclusion.

In addition, through discussions with the management of BUMDes Cibalanarik, it is hoped that with the participation of academics, BUMDes management can increase their understanding and insight on BUMDes management so that Regional Regulation No. 6 of 2016 can be implemented.

According to Sugiyono (2014), explains that: Qualitative research 
methods are research methods based on the philosophy of positivism, used to examine natural conditions of objects, (as opposed to experiments) where researchers are as key instruments, sampling data sources is done purposively and snowbaal, collection techniques with triangulation, data analysis is inductive / qualitative, and qualitative research results emphasize meaning rather than generalization.

While the interview is used as a data collection technique if the researcher will carry out a preliminary study to find problems that need to be investigated, and also the researcher wants to know things from respondents in more depth and the number of respondents is small / small (Sugiyono: 2014).

Zuhairini et al (1993) argued, the discussion method is the method in studying materials or conveying materials by road discuss it so that it results in understanding and change student behavior. To introduce the implementation of the BUMDes Implementation, the writer asks the management to discuss in order to further discuss the management of BUMDes. The discussion was conducted in one day with a question and answer process in which the agaragar officials could manage management.

In addition, with the existing rural potential in order to produce products that are able to compete in the middle of the free market, BUMDes can also take advantage of UMKMs in Cibalanarik Village. This is in accordance with previous research where UMKMs, especially Cibalanarik Village, in addition to being able to compete, also have a sustainable business and can provide a multiplier effect (Tine Badriatin, Lucky Radi Rinandiyana, Elis Listiana Mulyani : 2018).

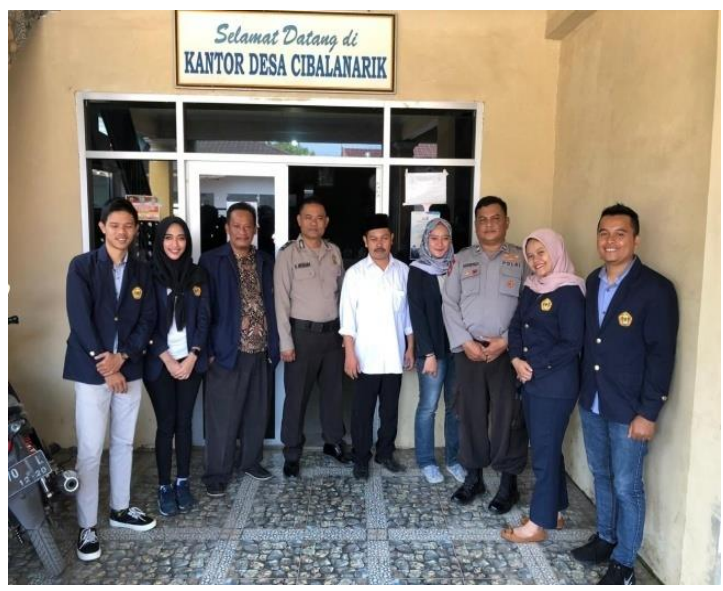


Figure 1. Discussion with BUMDes Managemet

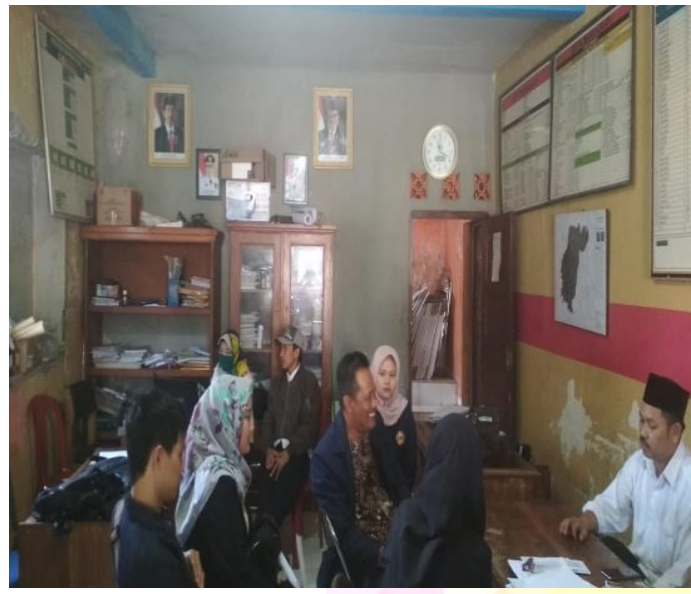

Figure 2 : Management of the Cibalanarik BUMDes

\section{Result and Discussion}

Management of Village Owned Enterprises (BUMDes) in Cibalanarik village is still less than optimal where it can be seen from the products produced from BUMDes itself that are still on a small scale, for example business units are still in the form of small-scale traditional stalls. In its management, the Cibalanarik BUMDes still experiences various obstacles and challenges so that the business programs that are run are not in accordance with the plans and programs made previously.

In managing various efforts have been carried out but still suffer losses this is allegedly still weak supervision in its management. The resulting business units are still traditional in nature, as seen from financial management which is only open to saving, this is because they still think that village funds are grants from the government so they only accommodate to make savings, even though they can be utilized with innovation and the use of industrial technology in BUMDes. Cibalanarik uses its new technology to enter only Brilink which is a smart behavior service issued by Bank BRI to conduct banking transactions.

The BUMDes business that is run in the village of Cibalanarik is still traditional in nature, that is, it is still in the form of a traditional stall where it still needs to be developed further in order to produce maximum results. We can see this Cibalanarik BUMDes business as in the picture below.

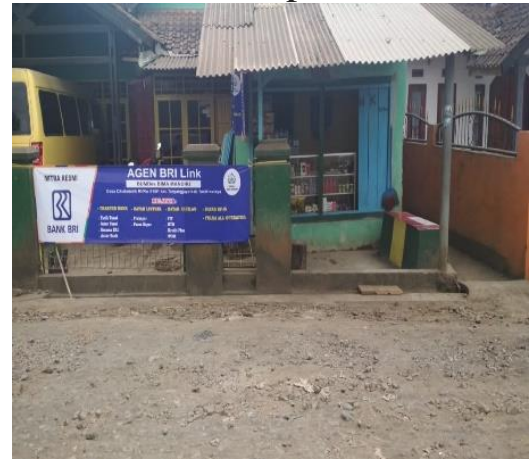


Figure 3: BUMDes Business Place

Therefore the purpose and aim of this community service is to provide an explanation and management of BUMDesa in order to always be able to produce business with an orderly business management, an orderly culture of customer service. This is consistent with previous research Anwar Sadat, Mahyudin, Hastuti (2018)

\section{Conclusion}

Based on the results of the study showed that the implementation of the management of Village-Owned Enterprises (BumDes) Cibalanarik, Tanjungjaya District, Tasikmalaya Regency. Implementation can be effective by fulfilling aspects of achieving policy objectives, availability of resources, ability of BumDes implementers / managers, enthusiasm for building and developing BumDes is needed, and the ability to communicate with various parties so that later economic prosperity will be achieved where the management system that is undertaken is also in line with developments times must be able to utilize technology which will hopefully change from a traditional economic system to a modern one.

\section{REFERENCES}

Anwar Sadat, Mahyudin, Hastuti. (2018). Penguatan Kelembagaan BUM Desa Menjadi Kekuatan Baru Ekonomi di Desa Wajah Jaya dan Desa Mulia Jaya Kabupaten Buton. Jurnal Pengabdian Kepada Masyarakat MEMBANGUN NEGERI. Universitas Muhammadiyah Buton, Vol.2, No.2, Oktober 2018. 103 - 119.

Grindle, Merilee S. 1980. Politics and Policy Implementation in The Third World. New Jersey: Princeton University Press.

Harmiati, Abdul Aziz Zulhakim. (2017). Eksistensi Badan Usaha Milik Desa (BUMDes) Dalam Mengembangkan Usaha dan Ekonomi Masyarakat Desa yang Berdaya Saing di Era Masyarakat Ekonomi ASEAN. Retrieved from : Jurnal Unihaz Bengkulu, Cluster Ekonomi. Setnas ASEAN.

Meter, Donald S. Van dan Horn, Carl E. Van. 1975. "The Policy Implementation Process: A Conceptual Frame-work" di dalam Administration and Society, Vol.6, No.4.

Peraturan Daerah Kabupaten Tasikmalaya Nomor 6 Tahun 2016 tentang Pengelolaan Badan 
Usaha Milik Desa.

Sugiyono. (2014) Metode Penelitian

Kuantitatif Kualitatif dan R\&D.

Bandung: Alfabeta.

Tine Badriatin, Lucky Radi

Rinandiyana, Elis Listiana

Mulyani. (2018). Pemasaran

Produk UMKM Binaan Pada

Pasar Keuangan Rakyat. Jurnal

Masyarakat Mandiri (JMM),

Vol.2., No.2, Desember 2018.

$149-153$.

Pemerintah Desa

Peraturan Desa

Zuhairini, et al. (1993). Metodik Khusus Pendidikan Agama, Surabaya: Usaha Ofset Printing, 1993. 